\title{
Effects of Input Modality, Vocal Rehearsal and Stimulus Length on Phonological Working Memory in Children with and without Speech Sound Disorders
}

\author{
Eun-Hye Jeon ${ }^{\mathrm{a}}$, Ji-Wan $\mathrm{Ha}^{\mathrm{a}, \mathrm{b}}$ \\ ${ }^{a}$ Department of Speech and Language Pathology, Graduate School of Rehabilitation, Daegu University, Gyeongsan, Korea \\ ${ }^{b}$ Department of Speech Pathology, Daegu University, Gyeongsan, Korea
}

Correspondence: Ji-Wan $\mathrm{Ha}, \mathrm{PhD}$ Department of Speech Pathology, Daegu University, 201 Daegudae-ro, Jillyang-eup, Gyeongsan 38453, Korea

Tel: $+82-53-850-4327$

Fax: +82-53-850-4329

E-mail: jw-ha@daegu.ac.kr

Received: January 20, 2021

Revised: February 13, 2021

Accepted: February 13, 2021

This research was supported by the Daegu University Research Grant, 2020.

This work was an excerpt from the master's thesis of the first author.

\begin{abstract}
Objectives: The purpose of this study was to look at different variables (input modality, rehearsal condition, stimulus length) that may affect phonological working memory in children with speech sound disorders (SSD) and typically developing (TD) peers. Methods: 18 children with SSD and 21 TD peers participated in this study. They performed delayed digit span tasks according to three variables (visual input vs. auditory input, rehearsal vs. rehearsal inhibition, 4 digits vs. 6 digits). Retrieval and sequencing scores of task performances were compared between two groups. Results: First, the two groups did not show significant differences in retrieval scores. The main effects of input modality, rehearsal condition and stimulus length were significant, and the interaction effect among three variables was significant on retrieval scores. In the rehearsal condition, there was a benefit of visual input regardless of stimulus lengths, but in the rehearsal inhibition condition, its benefit appeared only in 4 digits. Second, the sequencing ability was not significantly different in both groups. All main effects were significant, and the interaction effect among three variables was significant on sequencing scores like on retrievals. There was significant interaction effect between rehearsal condition and group. The TD group's sequencing performance was better than the SSD group in the rehearsal condition, but there were no significant differences between the two groups in the rehearsal inhibition condition. Conclusion: Visual inputs, rehearsal condition, and short stimulus lengths are positive for phonological working memory performance in both groups. However, the rehearsal strategy was not as effective in children with SSD as it was with TD children.
\end{abstract}

Keywords: Speech sound disorder, Phonological working memory, Delayed digit span task, Visual input, Vocal rehearsal, Stimulus length 작업기억(working memory)은 제한된 시간 동안 정보를 보유하 는 단기기억(short-term memory)의 기능에, 이해, 학습, 추론적 사 고 등 정보 간 복잡한 관계 해결을 위해 이들을 조작하는 처리기능 이 더해진 기억체계이다(Choi, 2014). 작업기억의 구성요소는 음운 루프(phonological loop), 시공간 잡기장(visuospatial sketchpad), 중앙집행기(central executive), 일화적 완충기(episodic buffer)인데, 이 중 음운루프는 청각적 또는 시각적으로 입력된 언어정보를 직접
받아들이기 때문에 언어영역과 가장 관련이 깊다. 음운루프는 언 어정보를 단기적으로 보유하는 음운저장소(phonological store)와 정보를 유지하기 위한 시연시스템(subvocal rehearsal)으로 이루어 져 있다. 청각적 언어정보인 구어는 그 자체가 음운적 특성을 지니 고 있으므로 음운저장소에 바로 등록되는 반면, 시각적 언어정보 인 글자는 시연시스템을 통해 음운적 특성으로 전환된 후 등록되 는 것으로 알려져 있다(Baddeley, 2003). 한편, 음운기억(phonolog- 
ical memory)은 기억 속에 음운정보를 기호화(encoding)하거나 저 장하는 능력을 말하며 음운단기기억과 음운작업기억으로 나뉜다. 이 두 기억은 앞서 말한 단기기억과 작업기억과 마찬가지로 언어정 보를 일시적으로 보유한다는 공통적인 기능을 가지고 있지만 처리 기능이 동반되었는지에 따라 그 역할이 구분된다(Archibald \& Gathercole, 2006). 언어정보를 수동적으로 보유하는 저장소의 역 할만 하는 것이 음운단기기억이라면, 음운작업기억은 적극적인 시 연과정을 통해 사라지는 음운정보를 유지시키고, 결과적으로 장기 기억 속에 표상으로 저장되도록 기여한다(Lee \& Ha, 2018). 음운작 업기억은 음운루프 또는 시공간 잡기장에 입력된 정보의 처리과정 에서 이를 조정하고 통제하는 데에 관여하는 중앙집행기의 영향 또 한 받게 된다(Baddeley, 2003).

이러한 음운작업기억이 아동의 언어습득과정과 성인의 정상적 언어처리과정에 기여하는 역할에 대해서는 이미 여러 연구들을 통 해 입증된 바 있다(Baddeley, 2000, 2003; Baddeley, Hitch, \& Allen, 2009; Baddeley, Papagno, \& Vallar, 1988). 의사소통장애 분야에서 도 아동의 의사소통발달 결함 또는 성인의 의사소통능력 손실에 미치는 음운작업기억의 영향에 대한 연구들을 다수 관찰할 수 있 다(Alt \& Spaulding, 2011; Archibald \& Gathercole, 2006; Choi, 2014; Larrivee \& Catts, 1999; Vallar \& Papagno, 2002). 이 중 특히 말소리장애는 그 특성 혹은 원인을 음운작업기억과 연관하여 생 각해보지 않을 수 없는데, 그 이유는 말소리장애와 관련 있는 기저 요인들로 거론되는 말소리 지각의 결함, 구강운동감각 기능의 문 제, 음운처리능력 손상, 환경적 요인(Kim \& Shin, 2015) 중 마지막 환경적 요인을 제외하면 모두 음운작업기억 과제 수행력 저하와 직 접 혹은 간접적으로 관련이 있기 때문이다.

우선 말소리 지각에 대해서는 음운작업기억 평가 과제의 실시 방법과 관련하여 생각해보아야 할 부분이다. 음운작업기억력을 평 가하기 위해서는 숫자, 단어, 문장 또는 비단어 등을 들려준 후 그 것을 그대로 반복하게 하는 따라말하기 과제를 가장 많이 사용하 고 있는데, 이는 모두 청각적 자극 제시를 기반으로 한다. 말소리 지 각 결함을 동반한 말소리장애 아동의 경우 들려준 음운정보를 정 확하게 지각하지 못해 음운작업기억 과제의 수행 저하가 나타날 수 있고, 이는 결국 음운작업기억 결함으로 해석될 여지가 있다. 때 문에 과제 수행력이 낮게 나타난 것이 정보의 입력 단계의 어려움 으로 인한 것인지, 아니면 순수하게 음운작업기억의 결함으로 인 한 것인지를 보다 명확하게 파악할 필요가 있다.

또한 구강운동감각 기능의 문제는 시연활동을 관장하는 시연시 스템이 과연 말소리장애 아동에게도 효율적인 음운작업기억 구성 요소인지 대해 의문을 제기한다. 아동은 6세 경 새로운 정보들을
더 오랫동안 기억하기 위해 스스로 시연을 사용하기 시작한다 (Kim, 1997). 정보를 속으로 되뇌이는 내현적 시연(subvocal rehearsal)과 소리 내어 되뇌이는 외현적 시연(vocal rehearsal) 중, 어 린 아동의 경우 외현적 시현이 더 효과적이지만 점차 나이가 들면 서 내현적 시현도 외현적 시연만큼 효과적인 것으로, 그리고 성인 이 되면 내현적 시연이 보다 자연스러운 것으로 보고되었다(Kim \& Ha, 2019; Lee, Ha, Koo, Hwang, \& Pyun, 2016; Murray, 1965). 그 러나 내현적이든 외현적이든 모든 시연활동은 민첩한 조음운동을 바탕으로 이루어진다는 점을 상기할 필요가 있다. 더 나아가 빠른 속도로 얼버무리듯 진행되는 조음운동 동안 조음기관의 움직임에 대한 감각적 모니터링을 통해 순차적 말소리들을 일련의 음운정보 로 기호화할 수 있는 능력 또한 요구된다. 이는 분명 민감한 구강운 동감각 기능을 전제로 한 활동으로, 이에 대한 결함을 동반한다면 시연활동의 효과를 기대할 수 없을 것이다. 이와 관련하여 말소리 장애 아동의 경우 조음활동 자체와 이에 대한 모니터링의 부담으 로 인해, 시연활동이 오히려 음운작업기억의 효율성을 떨어뜨릴 수 있다는 가능성이 제기되기도 하였다(Kim \& Ha, 2019).

음운처리능력은 최근 들어 말소리장애의 기저요인으로 가장 많 이 언급되고 있는 영역이다. 음운처리란 말처리과정에서 음운정보 를 사용하는 모든 과정들을 말하는데, 음운인식, 음운정보회상, 음운기억 등을 그 예로 들 수 있다(Jung, Choi, \& Ha, 2015). 따라서 음운처리는 음운단기기억과 음운작업기억을 모두 포괄하는 보다 광범위한 개념으로, 음운처리능력의 손상이 곧 음운작업기억의 결 함을 의미한다고 해도 무리가 없을 듯하다. 그런데 이러한 음운처 리능력과 관련하여 말소리장애 집단에서 상반된 결과들을 보고한 연구들을 찾아볼 수 있다. 말소리장애 아동의 음운처리능력이 일 반 아동과 차이가 없다고 보고한 연구(Bishop \& Adams, 1990), 언 어장애 동반 여부에 따라 그 결과가 달리 나타난다고 보고한 연구 $(\mathrm{Kim} \& \mathrm{Ha}, 2019)$ 등이 그것이다. 이러한 상이한 결과들을 고려할 때, 말소리장애 아동의 음운처리능력 결함에 대해 보다 다양한 각 도에서 심층적으로 연구해볼 필요가 있다.

이상과 같은 이유로 말소리 지각의 결함, 구강운동감각 기능의 문제 및 음운처리능력 자체의 어려움과 같은 말소리장애 아동의 잠 재적 특성들이 이들의 음운작업기억 과제 수행에 실제로 부정적 영향을 미치는지를 알아볼 필요가 있다. 더불어 말처리와 관련된 여러 기능들이 여전히 발달 중에 있는 일반 아동의 경우에도 이에 대한 확인이 필요할 것이다. 따라서 본 연구에서는 이러한 요인들 을 변수로 하여 말소리장애 아동과 일반 아동의 음운작업기억 과 제 수행 능력을 비교해보고자 하였다. 말소리 지각 능력에 대해서 는 자극어를 청각적으로 들려준 경우와 시각적으로 보여준 경우 
를, 구강운동감각 기능에 대해서는 시연활동을 한 경우와 하지 않 은 경우를 각각 비교함으로써 그 영향을 알아볼 것이다. 음운처리 능력은 제시한 음운정보를 얼마나 많이, 그리고 정확하게 처리할 수 있는지에 대한 능력인 만큼, 음운처리 과제의 단어길이 효과 (word length effect)에 대해서는 대부분의 연구자들이 이견을 보이 지 않는 듯하다(Lee \& Sim, 2003; Kim \& Ha, 2019). 따라서 본 연구 에서도 자극어의 길이를 달리하여 대상자들의 음운작업기억 과제 수행력을 비교하고자 하였다.

어떤 과제를 사용하여 음운작업기억 능력을 측정할 것인지는 대 상자의 특성 및 연구 목적에 달라질 수 있다. 음운기억에 대한 선행 연구들을 살펴보면 대부분 숫자, 단어, 문장 또는 비단어 자극어를 이용하여 대상자들의 음운작업기억력을 평가하고 있다. 본 연구에 서는 자극어가 청각 뿐만 아니라 시각, 즉 글자로도 제시되기 때문 에, 대상 아동들은 글자 자극어를 부담없이 읽을 수 있어야 한다. 따라서 비단어, 단어 또는 문장보다는 숫자를 자극어로 채택하는 것이 실험 진행에 보다 용이할 것이다. 숫자를 이용한 음운기억 과 제는 바로 따라말하기와 거꾸로 따라말하기로 구분되며, 전자는 음운단기기억을, 후자는 음운작업기억을 평가하는 것으로 알려져 있다. 그러나 숫자 거꾸로 따라말하기를 이용할 경우 과제 수행 시 대상 아동이 시연활동을 했는지 여부를 명확하게 알 수 없다는 방 법적 제한점이 있다. 또한 선행연구에서 시연 횟수, 시연 시간, 시연 과 시연 사이의 간격 등 시연과정에서 나타날 수 있는 여러 변수들 이 과제 수행에 영향을 미치는 것으로 언급된 만큼(Lee et al., 2016; $\mathrm{Kim} \& \mathrm{Ha}, 2019)$, 통제된 조건에서 시연활동을 실시하게 하는 것 이 타당할 것이다. 이와 같은 이유로 본 연구에서는 숫자 따라말하 기 과제를 이용하되 자극 제시 후 일정 시간 이후 말하는 지연 따라 말하기 과제를 실시하여, 모든 대상자들로 하여금 정해진 지연시간 동안 동일한 횟수와 간격으로 시연활동을 하도록 하였다. 지연된 시간 동안 음운정보를 기억하기 위해 시연전략을 사용하게 되므 로, 해당 과제는 정보를 수동적으로 보유하는 단기기억이 아닌, 정 보에 대한 적극적 조작이 이루어지는 작업기억이 관여했다고 할 수 있다.

더불어 결과 분석, 즉 채점 방식에 대해서도 고민해 보아야 한다. 대부분의 음운작업기억 연구들은 정반응 수 또는 정확하게 인출 한 음절 또는 음소의 비율과 같은 방법으로 과제 수행력을 점수화 하였다. 그러나 연속적인 음운정보들을 성공적으로 기억하는 것은 음운정보 각각을 정확하게 인출하는 것뿐 아니라 그 정보들의 일 련의 순서까지도 정확하게 배열하는 능력을 의미한다(Rye \& Ha, 2018). 실제 언어산출 시 음운부호화 단계에서는 음소들이 병렬적 으로 선택되고 이후 적절한 순서대로 배열되는, 즉 인출과 배열이
라는 순차적 처리과정을 거치게 된다(Dell, Chang, \& Griffin, 1999). 이러한 언어처리이론에 바탕을 두어 인출과 배열점수를 구 분하여 분석한 선행연구들에서 일반 아동들도 인출보다 배열에서 더 어려움을 보이지만 장애를 동반한 경우 그 어려움이 더욱 두드 러진다고 보고된 바 있다(Hwang \& Ha, 2010; Rye \& Ha, 2018). 이 와 같은 선행연구들에 근거할 때 음운정보의 배열은 인출보다 보편 적으로 어려운 작업으로 보이며, 말소리장애 아동은 더욱 어려움 을 보일 가능성을 배제할 수 없다. 말소리장애 아동의 음운기억력 이 일반 아동과 차이가 없다고 결론 내린 모든 연구들이 인출점수 에만 근거하여 그 결과를 도출하였음을 상기할 때, 말소리장애의 음운작업기억 수행력 측정 시 인출점수 뿐만 아니라 배열점수도 분석하여 비교할 필요가 있다.

따라서 본 연구에서는 자극유형, 시연여부, 자극길이의 변수가 음운작업기억 수행에 미치는 영향을 알아보기 위해, 순수 말소리 장애 아동(children with pure speech sound disorder, pure SSD)과 일반 아동(typically developing peers, TD)을 대상으로 숫자 지연 따라말하기 과제의 수행력을 인출과 배열 측면에서 비교하였다. 즉, 해당 변수들이 음운작업기억 과제 수행에 유의한 영향을 미치 는지, 그 영향이 pure SSD와 TD에서 다른 양상으로 나타나는지를 확인하고자 하였다. 이에 따른 결과는 대상자 특성에 따라 음운작 업기억 능력을 평가하는 가장 타당한 방법이 무엇인지, 그리고 음 운작업기억 촉진을 위해 고려해야 할 점이 무엇인지에 대해 시사하 는 바가 있을 것이다.

\section{연구방법}

\section{연구대상}

본 연구의 대상자는 5세 6개월에서 6세 11 개월 사이의 pure SSD 18 명, TD 21 명으로, 총 39 명이다. 말소리장애 아동과 일반 아동 간 음운작업기억의 격차가 5 세부터 유의하게 벌어진다는 선행연구 결 과 $(\mathrm{Kim} \& \mathrm{Ha}, 2016)$ 에 근거하여, 이와 같은 연령대의 아동들을 대 상으로 하였다. 말소리장애 집단은 수용 및 표현언어 발달은 정상 수준임에도 말명료도에 특히 문제를 보여 전문 언어재활사에 의해 순수 말소리장애로 진단받은 아동들로, 진단기준은 다음과 같다. 첫째, 취학 전 아동의 수용언어 및 표현언어 척도(Preschool Receptive-Expressive Language Scale, PRES; Kim, Sung, \& Lee, 2003)에 서 통합 언어연령이 - $1 \mathrm{SD}$ 이상에 해당하고, 둘째, 수용-표현어휘력 검사(Receptive \& Expressive Vocabulary Test, REVT; Kim, Hong, Kim, Jang, \& Lee, 2009)에서 수용·표현어휘능력이 -1 SD 이상에 해당하고, 셋째, 우리말 조음 · 음운 평가(Urimal Test of Articula- 
tion and Phonology, U-TAP; Kim \& Shin, 2004)에서 단어 수준 자 음정확도가 - $2 \mathrm{SD}$ 이하에 해당하고, 넷째, 한국판 레이븐 검사(Korean-Coloured Progressive Matrices, K-CPM; Lim, 2004)에서 비언 어성 지능지수가 85 이상이거나 담당 치료사에 의해 실시된 기타 다 른 지능 검사에서 지능이 정상 범주에 해당하는 것으로 보고되었 고, 다섯째, 부모와 교사에 의해 감각적, 신경학적, 신체적, 정서적, 인지적 문제가 없는 것으로 보고된 아동들이다. 일반 아동 선정 기 준은 U-TAP의 단어 수준 자음정확도가 -1 SD 이상 범위에 속해야 하는 것을 제외하고, 나머지는 순수 말소리장애 집단과 동일하다.

두 집단 간 성별, 생활연령, PRES 수용 및 표현언어연령, REVT 수용 및 표현어휘력, $\mathrm{K}-\mathrm{CPM}$ 지능 점수에는 유의한 차이가 없었고 ( $p>.05)$, 자음정확도에서만 그 차이가 유의하였다 $(p<.01)$. 두 집단 의 기본 정보는 Table 1 과 같다.

\section{연구도구 및 실험방법}

항목 선정 및 과제 구성

의사소통장애가 있을 경우 4 음절부터 단어길이 효과가 민감하 게 반영된다는 선행연구 결과(Lee \& Sim, 2003; Lee \& Yim, 2017; $\mathrm{Kim} \& \mathrm{Ha}, 2019)$ 에 근거하여, 숫자 4개(4항목)와 숫자 6개(6항목) 로 이루어진 항목들로 자극어를 구성하였다. 자극어 내 숫자 배열 은 음운유사성 효과(phonological similarity effect)를 고려하였는 데, 이는 음운적으로 유사한 항목 간에는 음운적 경쟁관계가 유발

Table 1. Participants' characteristics in three groups

\begin{tabular}{lcc}
\hline & pure SSD group (N=18) & TD (N=21) \\
\hline Gender & 7 & 10 \\
Male & 11 & 11 \\
Female & $72.39(3.48)$ & $72.05(3.93)$ \\
Chronological age (mo) & & \\
PRES language age (mo) & $71.56(4.22)$ & $72.9(4.23)$ \\
Receptive & $68.89(5.14)$ & $70.62(4.59)$ \\
Expressive & & \\
REVT (raw score) & $67.22(4.81)$ & $68.81(8.74)$ \\
Receptive vocabulary & $70.89(11.17)$ & $79.71(7.86)$ \\
Expressive vocabulary & & \\
U-TAP & $90.56(5.72)$ & $99.45(1.25)$ \\
PCC (\%) & & \\
K-CPM & $104(9.06)$ & $109.42(9.59)$ \\
Intelligence score & & \\
\hline
\end{tabular}

Values are presented as mean (SD).

pure SSD = pure speech sound disorder; TD=typically developing; PRES=Preschool Receptive \& Expressive Language Scale (Kim, Sung, \& Lee, 2003); REVT = Receptive \& Expressive Vocabulary Test (Kim, Hong, Kim, Jang, \& Lee, 2009); U-TAP=Urimal Test of Articulation and Phonology (Kim \& Shin, 2004); PCC=percentage of consonants correct; K-CPM = Korean-Coloured Progressive Matrices (Lim, 2004).
되고 그로 인해 기억처리에 어려움이 가중된다는 이론이다(Baddeley, 2003). 예를 들어 ‘T, C, V, D, B, G'와 같은 배열은 알파벳 항 목마다 모음 /i/ 소리가 반복되고 음운적으로 유사한 자음들이 다 수 존재하기 때문에, ‘B, W, Y, K, R, X'처럼 비유사한 배열보다 기억 을 유지하는 것이 더 어렵다(Baddeley, 2003). 음운유사성 효과는 청각자극 뿐만 아니라 시각자극에도 적용되는데, 그 이유는 시각 정보인 글자도 음운루프의 시연시스템을 통해 음운정보로 전환된 후음운저장소에 등록되기 때문이다(Baddeley, 2003).

실험 자극어는 동일한 숫자가 반복되지 않도록 구성하였고, 숫 자 배열 시 음운유사성의 균형을 맞추기 위해 다음과 같은 노력을 기울였다. 먼저 한국어 특성을 고려하여 유사단어를 선정한 Chung의 연구(2012)와 Lee와 $\operatorname{Sim}$ (2003)의 말소리 배치 규칙을 참 고하여, 1 부터 9 까지의 숫자 간 음운적 유사성의 판단기준을 정하 였다. 첫 번째, 동일한 음소가 있는 경우, 두 번째, 동일한 모음이 있 는 경우, 세 번째, 음절구조가 유사한 경우로, 이 중 첫 번째 기준을 만족하면 우선적으로 유사성이 높은 숫자들로 간주하였다. 이후 두 번째와 세 번째 순으로 판단기준을 삼았다. 이 기준을 적용해 음운적으로 유사한 숫자 배열과 유사하지 않은 숫자 배열로 이루어 진 4항목과 6항목 실험 자극어 총 32개를 제작하였다(Appendix 1).

이후 32 개의 자극어를 음운적으로 유사한 숫자 배열 4항목, 6 항 목 각각 2 개씩과 음운적으로 비유사한 숫자 배열 4항목, 6 항목 각 각 2 개씩의 총 8 개 항목으로 구성된 A, B, C, D 세트로 분류하였다. 본 연구의 실험과제는 자극유형과 시연여부에 따라 청각적으로 자 극이 주어지고 외현적 시연을 실시한 과제(청각자극-시연 과제), 청 각적으로 자극이 주어지고 시연을 억제한 과제(청각자극-시연억제 과제), 시각적으로 자극이 주어지고 외현적 시연을 실시한 과제(시 각자극-시연 과제), 시각적으로 자극이 주어지고 시연을 억제한 과 제(시각자극-시연억제 과제)와 같이 4 가지 세부과제로 나누어진다. 동일한 세부과제에 동일한 자극어가 반복되는 것을 통제하기 위 해, 각각의 세부과제에 대해 A, B, C, D 자극어 세트로 구성된 4 가 지 버전을 제작하였다. 예를 들어, $\mathrm{A}$ 세트에서 청각자극-시연 과제 에 사용된 항목들은 $\mathrm{B}$ 세트에서 청각자극-시연억제 과제에 사용되 었고, $\mathrm{C}$ 세트에서는 시각자극-시연 과제에, $\mathrm{D}$ 세트에서는 시각자극시연억제 과제에서 사용되었다. 또한, 대상자마다 다른 버전의 세 부과제를 제시하였는데, 예를 들어 시각자극-시연억제 과제를 실 시할 때 대상자의 $1 / 4$ 은 $\mathrm{A}$ 세트, $1 / 4$ 은 B세트, $1 / 4$ 은 C세트, 마지막 $1 / 4$ 은 $\mathrm{D}$ 세트 자극어로 구성된 실험과제를 제시하였다. 이와 같은 방식으로 자극유형, 자극길이 이외에 자극어의 다른 특성이 외생 변수로 작용할 가능성을 통제하였다. 
전산화 숫자 지연 따라말하기 과제 제작

취학전 아동에게 외현적 시연을 실시하게 했을 때 5 회가 가장 효 율적이었다는 선행연구(Lee \& Yim, 2017)에 근거하여, 시연횟수를 5 회로 설정하였다. 언어치료학과 학부생과 대학원생 20 명을 대상으 로 가장 긴 자극어인 6 배열 항목을 천천히 외현적 시연을 하도록 하 였고, 그 결과 시연에 소요된 평균 시간이 13 초임을 확인하였다. 이 를 근거로 하여 13 초의 시연 또는 시연억제 시간을 삽입한 지연 숫자 따라말하기 과제를 제작하였다. 모든 세부과제들은 DmDx Display software (Forster \& Forster, 2003)를 이용하여 전산화 과제로 제작 되었다. 과제에 사용된 청각자극은 오드캐스트의 TTS (Text to speech) 프로그램을 이용하여 녹음파일로 저장한 후 Gold Wave로 편집하였고, 시각자극은 PPT로 제작한 후 $\mathrm{bmp}$ 파일로 변환하였다.

\section{시연 과제}

시연 과제는 자극유형에 따라 청각적으로 자극이 주어지고 시연 을 실시한 과제와 시각적으로 자극이 주어지고 시연을 실시한 과제 로 나뉜다. 전자는 숫자 배열 항목을 청각적으로 보여준 뒤, 후자는 시각적으로 들려준 뒤 시연을 5 회 실시하게 하고 바로 그 항목을 다 시 말하게 하는 과제이다. 시연에는 기억해야 할 정보를 소리 내어 반복하는 외현적 시연과 소리내지 않고 반복하는 내현적 시연이 있 지만, 본 연구에서는 실험의 용이성과 시연 회수 및 간격의 일관성 을 위해 시연 조건을 외현적 시연으로 한정하였다. 주의집중을 유 도하기 위해 +표시가 $1,000 \mathrm{~ms}$ 동안 제시되고, ISI (inter stimuli interval) 후 숫자 배열이 청각적으로 들리거나 시각적으로 제시된다. 이때 청각자극과 시각자극이 제시되는 시간은 동일하게 하였고, 숫 자 배열은 DMDX에 의해 무작위 순서로 제시되었다. 숫자 배열 제
시 후 $13,000 \mathrm{~ms}$ 의 시간이 주어지고, 이때 아동은 외현적 시연을 5 회 실시하여야 하는데, 시연 횟수를 통제하기 위해 5 개의 칸에 일정 한 시간간격으로 색깔이 입혀지는 방법을 사용하였다. 시연을 실시 한 후 바로 “삐.” 하는 소리와 함께 '시작'이라는 글자가 보여지면 듣 거나 보았던 숫자 배열을 말해야 하고, 반응은 $\mathrm{DMDX}$ 에 의해 자동 적으로 녹음된다. 이와 같은 외현적 시연 과제 구성의 예는 Figure 1 과같다.

\section{시연억제 과제}

시연억제를 위한 여러 방법들이 있는데, 대표적으로 기억해야 할 정보를 되뇌이지 못하게 무의미한 말(예: 'the')을 반복하게 하는 방 법이 있다(Fletcher \& Bray, 1996; Chung, 2012). 이는 의식적으로 정보와 관련 없는 말을 소리 내어 반복하게 함으로써 의식적 또는 무의식적으로 일어나는 시연을 차단하고자 함이다. 이러한 선행연 구를 참고하여, 본 연구에서도 시연을 억제하기 위해 13 초 동안 /더/를 소리 내어 7회 반복하게 하였다. 시연 대신 /더/를 반복하는 것을 제외하고는 시연 과제와 동일하다. 주의집중을 유도하기 위해 +표시가 $1,000 \mathrm{~ms}$ 동안 제시되고, ISI 후 숫자 배열이 청각적으로 들리거나 시각적으로 제시된다. 이때 청각자극과 시각자극이 제시 되는 시간은 동일하게 하였고, 숫자 배열은 $\mathrm{DMDX}$ 에 의해 무작위 순서로 제시되었다. 숫자 배열 제시 후 $13,000 \mathrm{~ms}$ 의 시간이 주어지 고, 이때 화면에는 /더/라는 글자가 7회 깜빡이며 나타나게 되는데, 글자가 나타날 때마다 소리 내어 “더”라고 말해야 한다. 이 후 “삐-” 하는 소리와 함께 '시작'이라는 글자가 보여지면 듣거나 보았던 숫 자 배열을 말해야 한다. 이와 같은 시연 억제 과제 구성의 예는 Figure 2 와같다.

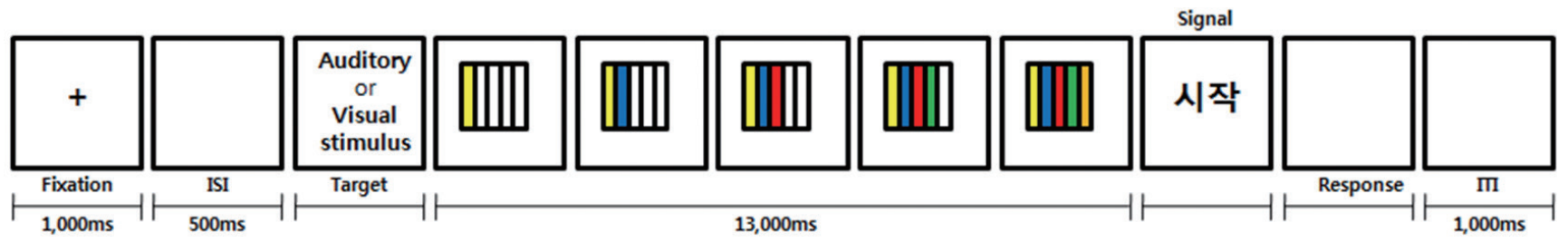

Figure 1. Rehearsal task.

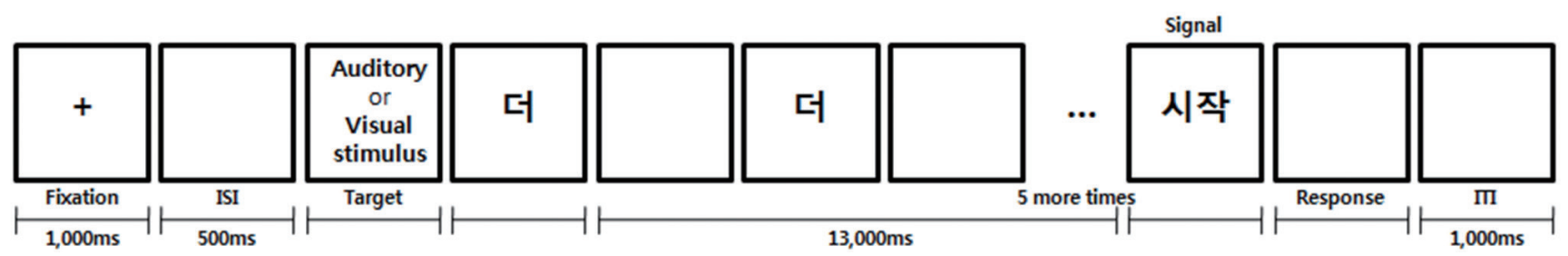

Figure 2. No rehearsal task. 


\section{실험절차}

사전검사와 본 실험은 소음이 차단된 장소에서 연구자와 일대일 로 진행되었고, 한 아동당 총 3 회기에 걸쳐 이루어졌다. 1 회기에는 사전검사 중 REVT, U-TAP, K-CPM을, 2회기에는 PRES를, 3 회기 에는 본 실험을 실시하였다. 1 회기와 2 회기는 각각 약 40 분씩, 3 회 기는 약 30 분이 소요되었다. 본 실험 시에는 노트북으로 숫자를 읽 는 데에 어려움이 없는지 먼저 확인한 후 실험과제를 제시하였다. 아동은 헤드셋을 낀 채 노트북과의 거리를 약 $50 \mathrm{~cm}$ 로 유지하며 실험에 임하였다. 스마트폰(iPhone XS)을 사용하여 전체 실험과정 이 녹음되었다. 검사자는 아동의 반응을 즉석에서 받아 적었고, 응 답 중 불명료한 발음이 있을 경우 스마트폰 또는 DMDX 소프트웨 어에 저장된 녹음파일을 반복 재생하여 해당 반응을 다시 확인하 는 과정을 거쳤다. 모든 대상자들은 시연억제 과제를 먼저 실시한 후 시연 과제를 실시하였는데, 이는 시연이 학습되는 것을 방지하기 위함이었다. 또한 시연 과제, 시연억제 과제 내에서는 대상자마다 청각자극과 시각자극 제시 순서를 달리하여, 특정 세부과제가 정 해진 순서에 고정적으로 실시되지 않도록 하였다.

\section{자료처리}

\section{인출점수를 이용한 숫자 따라말하기 수행력 측정}

인출점수는 정확하게 인출된 숫자에 각 1 점씩 부과한 후, 제시된 항목의 숫자 개수에 대한 백분율로 구하였다. 인출점수 계산 시에 는 숫자들이 어느 위치에서 산출되었는지는 고려하지 않는다. 즉, 자극어와 동일한 숫자가 반응 중 어떤 위치에서든 포함되어 있으면 정확하게 인출한 것으로 간주한다. 예를 들어 ' 1834 '에 대해 ' 2743 ' 으로 반응한 경우 자극어와 반응어에 공통으로 포함된 숫자는 ' 3 ' 과 ‘'의 2 개이므로 2 점을 부과하고, 자극어의 항목 수가 4 개이므로 2 를 4 로 나눈 후 100 을 곱하여 인출점수는 50 이 된다. 정확한 숫자 라 할지라도 2 회 이상 중복 산출된 경우 1 번만 인정한다. 예를 들어 '569438'을 ‘559427'로 산출한 경우 ' 5 '를 두 번 산출했지만, 이에 대 해서는 한 번만 인정하여 1점만 부여한다.

\section{배열점수를 이용한 숫자 따라말하기 수행력 측정}

배열점수는 초두효과와 최신효과를 고려한 Ryu \& $\mathrm{Ha}$ (2018)의 채점방식을 사용하였다. 초두효과와 최신효과는 순차적 정보에서 제일 처음(초두) 입력된 정보와 제일 마지막(최신)에 입력된 정보가 가장 기억하기 쉽다는 기억처리의 특성이다(Gupta, 2005). 이러한 선행연구와 이론을 참고하여 항목의 첫 숫자와 마지막 숫자를 기준 으로 산출된 숫자가 자극어와 동일한 위치에 배열되었을 경우 1점 씩을 부과한 후 이를 합산하여 백분율로 배열점수를 구하였다. 예
를 들어 ‘8437’을 ‘ 847 '로 산출한 경우, 첫 숫자 ‘ 8 '을 기준으로 제시 된 항목과 동일한 위치에서 산출된 숫자는 ' 8 '과 ' 4 '의 두 개이므로 2점(순배열 점수)이고, 마지막 숫자 '7’을 기준으로 제시된 항목과 동일한 위치에서 산출된 숫자는 ‘7’의 하나이므로 1점(역배열 점수) 이다. 이 두 점수를 합산한 3점을 항목의 개수로 나눠주는데, 이 때 주의할 점은 하나의 항목이 순배열, 역배열 점수를 위해 두 번 사용 되었으므로 항목 개수도 두 배가 되어야 한다는 것이다. 따라서 배 열점수는 $\{($ 순배열, 역배열 합산 점수 $) /$ 항목 개수 $\times 2\} \times 100$ 으로 계 산된다. 따라서 ' 8437 '을 ' 847 '로 산출한 경우 순배열과 역배열 점수 를 합한 3 점을 항목 개수를 두 배 한 8 로 나눈 후 100 을 곱하게 되 므로, 최종 배열점수는 37.5 가 된다. 반복 산출된 숫자는 인출점수 에서와 마찬가지로 중복 계산하지 않는다.

\section{통계분석}

자료의 통계처리는 SPSS (Statistics Package for the Social Science, version 18.0 for Window)를 이용하였고, 구체적인 분석 방법 은 다음과 같다. 첫째, 두 집단(pure SSD, TD) 간 자극유형(청각적 자극, 시각적 자극), 시연여부(시연 조건, 시연억제 조건), 자극길이 (4항목, 6항목)에 따라 숫자 따라말하기 인출점수에 유의한 차이가 있는지 알아보기 위해, 1 피험자 간-3 피험자 내 혼합설계에 따른 반 복측정분산분석(repeated measure ANOVA)을 실시하였다. 둘째, 두 집단(pure SSD, TD) 간 자극유형(청각적 자극, 시각적 자극), 시 연여부(시연 조건, 시연억제 조건), 자극길이(4항목, 6항목)에 따라 숫자 따라말하기 배열점수에 유의한 차이가 있는지 알아보기 위 해, 1 피험자 간-3 피험자 내 혼합설계에 따른 반복측정분산분석을 실시하였다. 구형성을 만족하지 못하는 경우 Greenhouse-Geisser 값을 이용하여 분석하였고, 상호작용효과 검정을 위해서는 COMPARE 하위명령 Syntax를 입력하여 사후검정을 실시하였다.

\section{연구결과}

\section{두 집단 간 자극유형, 시연여부 및 자극길이에 따른 숫자 따라말하기 인출점수 비교}

두 집단 간 자극유형, 시연여부 및 자극길이에 따른 숫자 따라말 하기 인출점수에 대한 기술통계는 Table 2 와 같다. 통계적 유의성 검정결과 두 집단 간차이가 유의하지 않아 $\left(F_{(1,37)}=1.168, p>.05\right)$, pure $\mathrm{SSD}$ 도 TD만큼 인출 수행력이 양호함을 알 수 있었다. 그러나 집단 내 변수에서는 그차이가 모두 유의한 것으로 나타났다. 즉, 자극유형 에 따른 주효과 $\left(F_{(1,37)}=15.134, p<.05\right)$, 시연여부에 따른 주효과 $\left(F_{(1,37)}=192.376 p<.05\right)$, 자극길이에 따른 주효과 $\left(F_{(1,37)}=36,293.944\right.$, 
Table 2. Descriptive analysis on the scores of digit span task in two groups (retrieval score)

\begin{tabular}{|c|c|c|c|c|c|}
\hline \multirow{2}{*}{ Task condition } & \multirow{2}{*}{$\begin{array}{l}\text { Number } \\
\text { of digit }\end{array}$} & \multicolumn{2}{|c|}{ pure $S S D$ group $(N=18)$} & \multicolumn{2}{|c|}{ TD group ( $N=21)$} \\
\hline & & Mean & SD & Mean & SD \\
\hline \multicolumn{6}{|l|}{ Auditory input } \\
\hline \multirow[t]{2}{*}{ Rehearsal } & 4 & 75.35 & 22.02 & 84.23 & 17.64 \\
\hline & 6 & 49.80 & 18.55 & 54.17 & 23.50 \\
\hline \multirow[t]{2}{*}{ No rehearsal } & 4 & 44.79 & 20.59 & 42.26 & 27.45 \\
\hline & 6 & 30.79 & 16.74 & 26.98 & 19.88 \\
\hline \multicolumn{6}{|l|}{ Visual Input } \\
\hline \multirow[t]{2}{*}{ Rehearsal } & 4 & 81.60 & 17.87 & 93.45 & 7.260 \\
\hline & 6 & 62.73 & 19.41 & 70.83 & 24.15 \\
\hline \multirow[t]{2}{*}{ No rehearsal } & 4 & 57.29 & 29.95 & 56.55 & 27.35 \\
\hline & 6 & 28.47 & 15.28 & 38.69 & 17.78 \\
\hline
\end{tabular}

pure $S S D=$ pure speech sound disorder; $T D=$ typically developing .

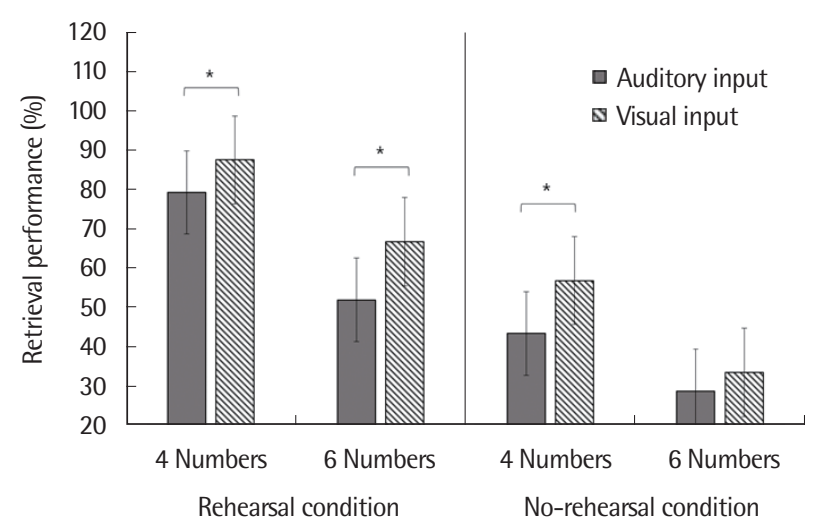

Figure 3. Retrieval performance according to input modality, vocal rehearsal and stimulus length conditions. ${ }^{*} p<.05$.

$p<.05)$ 가 유의하여, 두 집단 모두에서 시각적으로 자극이 제시될 때, 외현적 시연이 동반될 때, 자극의 길이가 짧을 때 인출 수행력이 유의 하게 좋은 것으로 나타났다.

또한 자극유형, 시연여부, 자극길이의 삼요인 상호작용효과도 유 의하였다 $\left(F_{(1,37)}=1205.689, p<.05\right)$. 사후검정 결과, 외현적 시연 조 건에서는 4항목과 6항목 모두에서 청각자극보다 시각자극의 수행 력이 유의하게 좋았으나 $(p<.05)$, 시연억제 조건에서는 자극길이에 따라 그 양상이 달러졌다. 즉, 시연억제 조건의 경우 4 항목에서는 마찬가지로 시각자극에서의 수행력이 유의하게 좋았던 반면 ( $p<.05), 6$ 항목에서는 자극유형 간 차이가 없다는 것을 확인할 수 있었다 $(p>.05)$ (Figure 3$)$.
Table 3. Descriptive analysis on the scores of digit span task in two groups (sequencing score)

\begin{tabular}{|c|c|c|c|c|c|}
\hline \multirow{2}{*}{ Task condition } & \multirow{2}{*}{$\begin{array}{l}\text { Number } \\
\text { of digit }\end{array}$} & \multicolumn{2}{|c|}{ pure $S S D$ group $(N=18)$} & \multicolumn{2}{|c|}{ TD group ( $N=21$ ) } \\
\hline & & Mean & SD & Mean & SD \\
\hline \multicolumn{6}{|l|}{ Auditory input } \\
\hline \multirow[t]{2}{*}{ Rehearsal } & 4 & 61.63 & 30.80 & 76.49 & 25.84 \\
\hline & 6 & 19.79 & 11.68 & 28.77 & 23.34 \\
\hline \multirow[t]{2}{*}{ No rehearsal } & 4 & 21.70 & 13.14 & 22.92 & 22.78 \\
\hline & 6 & 7.410 & 5.500 & 7.040 & 6.800 \\
\hline \multicolumn{6}{|l|}{ Visual Input } \\
\hline \multirow[t]{2}{*}{ Rehearsal } & 4 & 72.22 & 30.01 & 90.48 & 9.400 \\
\hline & 6 & 38.43 & 28.06 & 54.27 & 32.52 \\
\hline \multirow[t]{2}{*}{ No rehearsal } & 4 & 44.27 & 31.22 & 44.64 & 29.43 \\
\hline & 6 & 8.910 & 6.260 & 14.19 & 13.53 \\
\hline
\end{tabular}

pure $S S D=$ pure speech sound disorder; $T D$ = typically developing .

\section{두 집단 간 자극유형, 시연여부 및 자극길이에 따른 숫자 따라말하기 배열점수 비교}

두 집단 간 자극유형, 시연여부, 및 자극길이에 따른 숫자 따라말 하기 배열점수에 대한 기술통계는 Table 3과 같다. 통계적 유의성 검정결과, 두 집단 간 숫자 따라말하기 배열점수에 유의한 차이가 없었으나 $(F(1,37)=3.191, p>.05)$, 집단 내 자극유형에 따른 주효과 $\left(F_{(1,37)}=35.154, p<.05\right)$, 시연여부에 따른 주효과 $\left(F_{(1,37)}=307.160\right.$ $p<.05)$, 자극길이에 따른 주효과 $\left(F_{(1,37)}=36,293.944, p<.05\right)$ 가 유 의하였다. 즉, 인출과 마찬가지로 배열점수에서도 자극이 시각적으 로 제시될 때, 외현적 시연이 동반될 때, 자극의 길이가 짧을 때, 두 집단 모두에서 수행력이 유의하게 좋았다.

또한 시연여부와 집단 간 상호작용효과 $\left(F_{(1,37)}=11.063, p<.05\right)$ 와 자극길이와 시연여부 간 상호작용효과 $\left(F_{(1,37)}=1205.689, p<.05\right)$ 가 유의하였다. 시연여부와 집단 간 상호작용 효과에 대한 사후검정 결과, 시연억제 조건에서는 두 집단 간 유의한 차이가 없었던 반면 ( $p>$.05), 외현적 시연 조건에서는 $\mathrm{TD}$ 의 배열 수행력이 pure SSD보 다 유의하게 좋은 것으로 나타났다 $(p<.05)$ (Figure 4). 자극길이와 시연여부 간 상호작용효과에 대한 사후검정 결과, 4 항목과 6 항목 모두에서 외현적 시연 조건의 수행력이 유의하게 좋았으나 $(p<.05)$, 그 차이가 4 항목에서 더욱 두드러지는 것을 알 수 있었다 $(p<.01)$.

자극유형, 시연여부, 자극길이의 삼요인 상호작용효과 또한 유의 하여 $\left(F_{(1,37)}=1205.689, p<.05\right)$, 이에 대한 사후검정을 실시하였다. 그 결과 외현적 시연 조건과 시각자극 조건의 수행력이 유의하게 좋은 것은 변함이 없었지만 $(p<.05)$, 자극길이에 따라 그 양상이 달 라짐을 확인할 수 있었다. 즉, 외현적 시연 조건에서는 시각자극의 


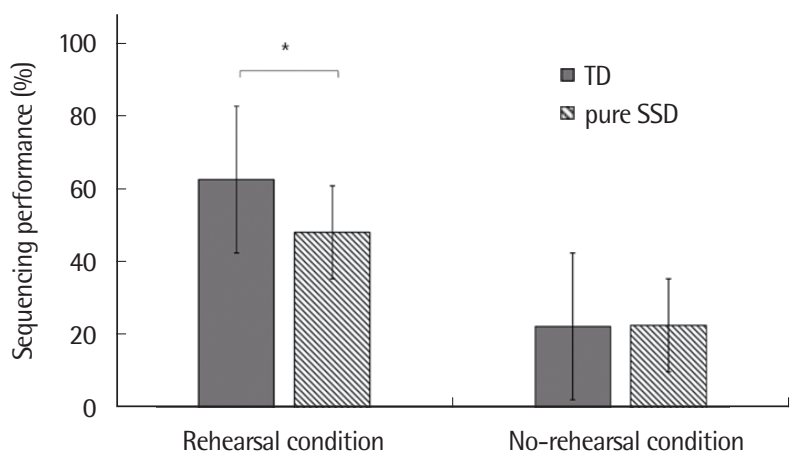

Figure 4. Sequencing performance according to rehearsal conditions in two groups.

pure SSD = pure speech sound disorder; $T \mathrm{D}=$ typically developing.

${ }^{*} p<.05$.

이득이 6 항목에서 두드러진 반면 $(p<.05)$, 시연억제 조건에서는 반 대로 4 항목에서 시각자극의 이득이 두드러졌다 $(p<.01)$ (Figure 5).

\section{논의 및 결론}

본 연구에서는 음운작업기억과 관련 있는 다양한 변수들(자극 유형, 시연여부, 자극길이)에 대해 살펴보고, 해당 변수들이 pure $\mathrm{SSD}$ 와 TD의 숫자 지연 따라말하기 과제 수행 시 미치는 영향을 인 출과 배열이라는 두 가지 측면에서 분석하였다. 그 결과 인출과 배 열점수 모두에서 집단 간 변수의 주효과는 나타나지 않았으나, 집 단 내 변수들의 주효과가 유의하였고 복잡한 상호작용효과들이 관 찰되었다. 이러한 결과들을 종합적으로 고찰해봄으로써, 본 연구 에 대해 보다 심도 깊게 접근해 보고자 한다.

우선 집단에 상관없이 자극유형, 시연여부, 자극길이라는 집단 내 변수 각각은 숫자 지연 따라말하기 과제의 인출과 배열 수행력 에 모두 유의한 영향을 미쳤다. 즉, 시각형태인 글자로 자극이 제시 되고, 외현적 시연활동을 동반하고, 자극길이가 상대적으로 짧으 면, 13 초라는 비교적 긴 지연시간에도 불구하고 음운정보들을 훨 씬 효과적으로 기억할 수 있었다. 시연여부와 자극길이가 숫자 지 연 따라말하기 과제에 미치는 유의한 영향에 대해서는 여러 선행연 구들(Baddeley, 2003; Cohen \& Heath, 1990; Fletcher \& Bray, 1996; Jacquemot \& Scott, 2006; Kim, 1997; Kim \& Ha, 2019; Lee et al., 2016; Salame \& Baddeley, 1982)에 근거하여 어느 정도 예측할 수 있었던 결과이다. 그러나 시각자극이 청각자극보다 기억 유지에 유 의하게 도움이 된다는 결과에 대해서는 좀 더 고찰해볼 여지가 있 다. 서론에서도 언급하였듯이, 청각자극인 구어는 그 자체가 음운 적 특성을 지니고 있기 때문에 음운저장소에 직접 입력되는 반면,

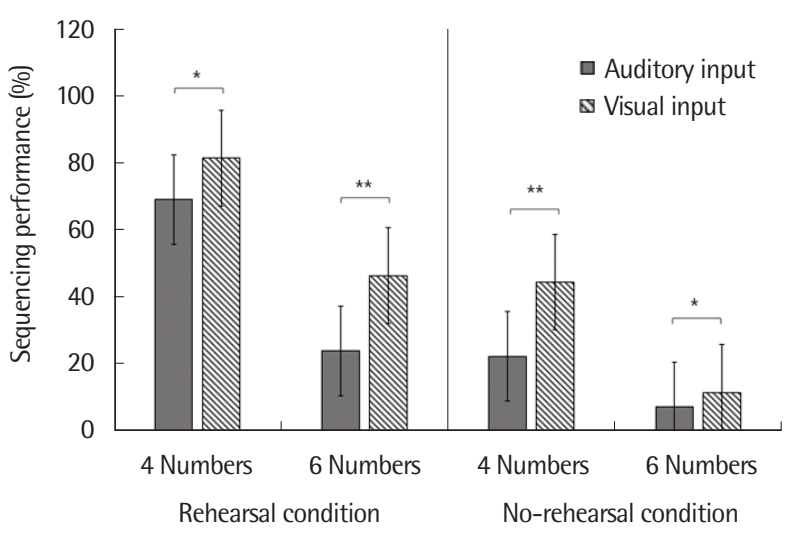

Figure 5. Sequencing performance according to input modality, vocal rehearsal and stimulus length conditions. ${ }^{*} p<.05,{ }^{* *} p<.01$.

이질적 특성을 가진 시각자극, 즉 글자는 시연시스템에서 음운정 보로 변환된 후에야 비로소 저장소에 등록될 수 있다(Baddeley, 2003). 이처럼 음운작업기억 시스템에서 의미 있는 정보가 되기까 지 상대적으로 복잡한 과정을 거치는 시각자극이 그렇지 않은 청 각자극보다 음운정보 유지에 오히려 유리하다는 결과는 다소 의외 였다.

그 이유에 대한 다양한 가능성들을 생각해볼 수 있지만, 본 연구 자들은 청각과 시각이라는 양식 자체의 특성에 초점을 두고자 한 다. 청각자극인 구어는 낱개의 정보들이 시간차를 두고 순차적으 로 입력되는 반면, 시각자극인 글자는 전체 정보가 한꺼번에 제시 된다. 청각자극에서는 다음 숫자를 듣기 위해 앞의 숫자는 더 이상 들리지 않아야 하는 반면, 시각자극에서는 다음 숫자와 함께 앞의 숫자를 여전히 볼 수 있다. 청각자극 기반의 과제들은 먼저 제시된 정보들이 사라지지 않도록 계속해서 되뇌어야 하고 동시에 나중에 제시된 정보들은 새롭게 받아들여야 하기 때문에, 상당한 주의집 중력을 요하는 인지적으로 부담감이 높은 과제임에 틀림없다. 이에 반해 익숙하고 친숙한 글자자극이 시각적으로 제시되는 과제의 경 우 일정 시간 동안 모든 정보들을 한 눈에 볼 수 있기 때문에 인지 적 부담감은 상대적으로 덜하다. 본 연구에서는 청각자극과 시각 자극이 제시되는 시간을 동일하게 하였기 때문에, 청각자극 과제 에서 4 개 또는 6 개의 숫자정보들이 순차적으로 주어지는 시간만 큼, 시각자극 과제에서는 전체 숫자정보들을 한 눈에 볼 수 있는 시 간이 허용되었다. 이와 같은 청각과 시각이라는 양식 자체의 본질 적 특성이 정보를 입력하고 보유하는 데에 상대적인 유불리로 작 용하였을 것으로 판단된다. 청각자극보다 시각자극이 언어정보를 기억하게 하는 데에 효과적이라고 보고한 선행연구(Kim 2016; $\mathrm{Kim} \& \mathrm{Ha}, 2016)$, 글자 습득 초기부터 음운처리 과제 수행 시 글자 
정보를 적극 활용한다는 선행연구(Kim \& Ha, 2016) 등은 이러한 주장을 뒷받침한다.

하지만 이 세 변수들을 동시에 고려할 경우 영향의 양상은 훨씬 복잡해진다. 세 변수 중 시연활동은 작업기억 모델의 하부 구성요 소로 인정될 정도로, 그것이 음운작업기억에 미치는 영향은 견고 해 보인다. 일반 아동 뿐만 아니라 말소리장애 아동의 언어발달과 정에서도 시연은 중요한 전략으로 자리잡고 있다(Lee et al., 2016; Kim \& Ha, 2019). 그러나 배열점수에서 외현적 시연의 효과가 6항 목보다 4항목에서 두드러졌다는 연구결과를 통해, 시연효과가 모 든 경우 동일하게 발휘되는 것은 아니라는 것을 알 수 있다. 즉, 인출 보다 난이도가 높은 배열 수행에서 자극이 길어지면 시연효과가 감 소되었다. 이는 대상자가 감당할 수 있는 정보의 양 내에서는 시연 활동이 매우 강력한 음운기억 촉진수단으로 작용하지만, 그 범위 를 벗어나면 시연효과를 기대할 수 없음을 시사한다. 따라서 시연 활동이 굳이 필요하지 않을 정도의 적은 정보, 시연효과를 기대할 수 없을 만큼의 많은 정보, 시연전략이 매우 효과적일 수 있는 적당 한 양의 정보 등에 대해 생각해보아야 할 것이며, 더불어 음운작업 기억 촉진을 위해 시연활동을 독려할 때에는 해당 과제에 적절한 정보의 양도 함께 고려해야 할 것이다.

또한 시연활동과 자극길이는 시각자극의 효과에도 영향을 미쳤 다. 앞에서도 언급하였듯이 시각자극은 청각자극보다 모든 경우 과 제 수행에 긍정적 영향을 주었다. 그러나 Figure 3을 살펴보면, 자극 길이가 긴 6항목을 인출할 때 시연활동을 하지 않으면 시각자극의 효과가 희석되어 청각자극과 차이가 없어진다는 것을 알 수 있다. 마찬가지로 Figure 4에서도 시연활동을 하지 않은 경우 6항목의 배 열 수행력은 4 항목보다 시각적 자극의 이득이 적게 나타났다. 정리 하면 긴 자극어에 대해 시연활동을 하지 않고 그 항목과 순서를 기 억하는 것은 매우 어려운 과제이며, 이 때에는 시각자극의 효과도 크게 기대하기 어렵다고 할 수 있다. 다시 말해 다른 변수가 도움이 되지 않는 상황에서는 특정 변수의 효력도 줄어든 것으로 보인다.

이상과 같이 살펴보았듯이, 음운작업기억 수행에 미치는 특정 변수의 영향을 단순하게 생각해선 안 될 것이다. 주어진 정보를 짧 지 않은 시간 보유하는 데에는 집단 내 여러 변수들이 서로 상호작 용하며 영향을 미쳤고, 뿐만 아니라 이러한 상호작용효과는 집단 변수에 대해서도 나타났다. 상호작용효과를 살펴보기에 앞서, pure $\mathrm{SSD}$ 와 TD의 두 집단 간 주효과가 유의하지 않았다는 결과부터 언 급할 필요가 있다. 본 연구결과 pure $\mathrm{SSD}$ 는 $\mathrm{TD}$ 만큼 성공적으로 인출과제와 배열과제를 수행하였다. SSD 집단의 음운기억에 대해 다루었던 Kim과 $\mathrm{Ha}$ 의 연구(2019)에서도 언어장애를 동반한 SSD 집단은 음운작업기억에 결함을 보였지만, 다른 장애를 동반하지
않은 pure SSD 집단은 음운작업기억 수행에 문제를 나타내지 않았 다. 이러한 결과로 인해 음운작업기억의 손상은 음운영역의 문제를 초래하고 이는 곧 언어결함으로 연결될 수 있음을 추측할 수 있다. 본 연구의 SSD 집단은 다른 영역에는 아무런 문제가 없고 말소리 산출에만 어려움을 보이는 pure SSD 아동들이었다. 이 집단의 평 균 자음정확도는 $90 \%$ 이상으로, 물론 $\mathrm{TD}$ 집단보다는 유의하게 떨 어졌지만, 크게 심각할 정도의 문제로는 보이지 않았다(Table 1). 조 음방법적으로 난이도가 높은 일부 음소에서만 산출에 어려움을 보이는 아동들이 대부분으로, 이들의 근본적 문제는 음운보다 조 음적 측면에 기인하고 있을 가능성이 높다. 따라서 이들이 $\mathrm{TD}$ 집단 과 음운작업기억 수행력에 유의한 차이가 나타나지 않았다는 것은 어쩌면 당연한 결과일 수 있다.

그러나 pure SSD 집단과 관련하여 주목해야 할 부분은 배열 수 행에서 시연여부와 집단 간 상호작용효과가 나타났다는 점이다 (Figure 4). 시연을 하지 않은 경우 두 집단 간 차이는 유의하지 않았 던 반면, 시연 조건에서는 pure SSD 집단의 수행력이 TD 집단보다 유의하게 떨어졌다. 두 집단 간 유의한 차이가 초래될 정도로 시연 효과가 $\mathrm{TD}$ 에서 월등히 높게 나타났다는 이와 같은 결과는 시연의 능숙도 혹은 효율성에 두 집단 간 차이가 있음을 시사한다. 이에 대 해서는 외현적 시연이 조음활동을 통해 이루어진다는 점, 그리고 시연을 통한 음운정보의 활성화가 구강운동감각 기능에 기반을 두 고 있다는 점을 상기할 필요가 있다. 조음능력이 취약하고 구강운 동감각 기능에 잠재적 결함이 있는 SSD 집단에서 $\mathrm{TD}$ 만큼 능숙하 게 시연을 하고 이를 통해 기억의 효율성을 극대화하기를 기대하는 것은 다소 무리가 있어 보인다. 그럼에도 불구하고 SSD 집단에서도 외현적 시연의 효과가 인출과 배열 모두에서 있었다는 점을 간과해 서는 안 될 것이다. 인출한 정보들을 정확한 순서로 배열하는 것은 어렵고 복잡한 음운처리 과제이다. 이러한 난이도 높은 작업을 수 행할 때 시연활동은 당연히 긍정적 효과가 있었으며, 이는 $\mathrm{TD}$ 뿐 아 니라 pure SSD 집단에도 해당되었다. 다만 시연활동이 TD만큼은 효율적이지 못하였다는 것이 확인된 만큼, 이를 보완할 수 있는, $\mathrm{SSD}$ 아동에게 적용 가능한 또 다른 음운기억 촉진전략에 대해 고 민해보아야 할 것이다.

상황, 맥락, 의미관계 등이 단서로 작용하여 별다른 노력 없이 머 릿속에 자연스럽게 남게 되는 의미정보와 달리, 음운정보는 그 어 떤 단서도 없기 때문에 의식적으로 소리조합을 기억해내는 수 밖에 없다. 새로운 어휘를 습득할 때, 외국어를 학습할 때, 조사, 어미 등 기능어를 발달시킬 때와 같이 언어를 배우는 여러 과정에서 그것 을 구성하는 음운정보를 보다 오래, 그리고 보다 정확하게 기억하 기 위해 여러 차례 소리 조합을 반복해서 되뇌어본 경험이 누구나 
있을 것이다. 이것이 바로 음운작업기억이며, 이 과정에서 우리는 시연전략을 자연스럽게 사용하고 있다. 따라서 언어의 음운정보를 정확하게 기억해내는 능력은 언어습득을 좌우하는 중요한 요소이 다. 무의미한 숫자조합을 오래 기억하는 데에 어떤 변수들이 영향 을 미치는지에 대한 본 연구결과는 효율적인 음운정보 습득방법에 대해 의미 있는 정보를 제공한다. 연구결과들을 종합적으로 정리 해보면 다음과 같은 결론을 얻을 수 있다. 글자에 익숙한 경우 글자 를 보여줌으로써, 오랜 시간 기억유지를 위해 시연활동을 적극 활 용함으로써, 기억폭에 부담이 되지 않을 정도의 적당한 정보 양을 제공함으로써, 아동의 음운기억을 촉진할 수 있다. 이 모든 것을 함 께 활용하는 것이 보다 효과적인데, 그 이유는 다른 변수가 도움이 되지 않는 상황에서는 특정 변수의 효력도 줄어들기 때문이다. SSD 집단이 언어장애를 동반하지 않고 말소리 산출에만 문제가 있 는 경우라면, 음운작업기억력이 취약할 것으로 염려하지 않아도 된다. 단, 보다 오랜 시간 음운정보를 유지하기 위해 시연전략을 사 용하는 것은 물론 이들의 음운기억 촉진에 도움이 되지만, $\mathrm{TD}$ 에서 만큼 효과적이지는 못하기 때문에, 이들에게 적절한 또 다른 보완 적 수단을 병행하는 것이 바람직하다.

\section{REFERENCES}

Alt, M., \& Spaulding, T. (2011). The effect of time on word learning: an examination of decay of the memory trace and vocal rehearsal in children with and without specific language impairment. Journal of Communication Disorders, 44(6), 640-654.

Archibald, L. M., \& Gathercole, S. E. (2006). Short-term and working memory in specific language impairment. International Journal of Language \& Communication Disorders, 41(6), 675-693.

Baddeley, A. (2000). The episodic buffer: a new component of working memory?. Trends in Cognitive Sciences, 4(11), 417-423.

Baddeley, A. (2003). Working memory and language: an overview. Journal of Communication Disorder 36(3), 189-208.

Baddeley, A., Hitch, G., \& Allen, R. (2009). Working memory and binding in sentence recall. Journal of Memory and Language, 61(3), 438-56.

Baddeley, A., Papagno, C., \& Vallar, G. (1988). When long-term learning depends on short-term storage. Journal of Memory and Language, 27(5), 586-595.

Bishop, D. V., \& Adams, C. (1990). A prospective study of the relationship between specific language impairment, phonological disorders and reading retardation. Journal of Child Psychology and Psychiatry, 31(7), 1027-
1050.

Choi, H. (2014). Verbal working memory and verbal memory's relationship to discourse comprehension in healthy elderly. Communication Sciences \& Disorders, 19(4), 513-522.

Chung, Y. S. (2012). The effect of manipulating the articulatory suppression behavior on the performance of working memory system (doctoral dissertation). Seoul University, Seoul, Korea.

Cohen, R. L., \& Heath, M. (1990). The development of serial short-term memory and the articulatory loop hypothesis. Intelligence, 14(2), 151-171.

Dell, G. S., Chang, F., \& Griffin, Z. M. (1999). Connectionist models of language production: Lexical access and grammatical encoding. Cognitive Science, 23(4), 517-542.

Fletcher, K. L., \& Bray, N. W. (1996). External memory strategy use in preschool children. Merrill-palmer Quarterly, 42(3), 379-396.

Forster, K. I., \& Forster, J. C. (2003). DMDX: a window display program with millisecond accuracy. Behavior Research Methods, Instruments, \& Computers, 35(1), 116-124.

Gupta, P. (2005). Primacy and recency in nonword repetition. Memory, 13(34), 318-324.

Hwang, J., \& Ha, S. (2010). Nonword repetitions of 2-to 5-year-old typically developing children. Korean Journal of Communication \& Disorders, 15 (4), 561-571.

Jacquemot, C., \& Scott, S. K. (2006). What is the relationship between phonological short-term memory and speech processing?. Trends in Cognitive Sciences, 10(11), 480-486.

Jung, I. K., Choi, S. Y., \& Ha, J. W. (2015). Internal awareness of phonological representation in children with speech sound disorders. Communication Sciences \& Disorders, 20(1), 48-59.

Kim, J. H. (2016). Information unit (IU) production of elderly's narrative discourse: a comparison between visual and auditory language stimuli (Master's thesis). Yonsei University. Seoul. Korea.

Kim, M. H., \& Ha, J. W. (2016). Effects of auditory and visual presentation on phonemic awareness in 5-to 6-year-old children. Phonetics and Speech Sciences, $8(1), 71-80$.

Kim, M. J., \& Ha, J. W. (2019). Effects of vocal rehearsal and auditory input enhancement on delayed nonword repetition performance in children with and without speech sound disorders. Communication Sciences \& Disorders, 24(1), 101-116.

Kim, O. H. (1997). Effects of continuity and interval time in verbal rehearsals on recall. Early Childhood Education Research \& Review, 1(2), 239-262. 
Kim, S. J., \& Shin, J. Y. (2015). Speech sound disorder. Seoul: Sigma Press.

Kim, Y. T., Hong, G. H., Kim, K. H., Jang, H. S., \& Lee, J. Y. (2009). Receptive \& expressive vocabulary test (REVT). Seoul: Seoul Community Rehabilitation Center.

Kim, Y. T., \& Shin, M. J. (2004). Urimal Test of Articulation and phonology (U-TAP). Seoul, Korea: Hakjisa.

Kim, Y. T., Sung, T. J., \& Lee, Y. K. (2003). Preschool receptive-expressive language scale (PRES). Seoul: Seoul Community Rehabilitation Center.

Larrivee, L. S., \& Catts, H. W. (1999). Early reading achievement in children with expressive phonological disorders. American Journal of Speech-Language Pathology, 8(2), 118-128.

Lee, E. J., \& Sim, H. S. (2003). Phonological memory in the nonword repetition of children: a comparison of functional phonologically disordered and normal children. Korean Journal of Communication \& Disorders, 8(2), 127-145.

Lee, K. E., \& Ha, J. W. (2018). Phonological short-term and working memory in 5- and 6-year-old children with speech sound disorders. Communication Sciences \& Disorder, 23(3), 713-724.

Lee, S., \& Yim, D. (2017). Nonword production performance according to vocal rehearsal condition in children with language delay. Communication
Sciences \& Disorders, 22(3), 471-484.

Lee, S. J., Ha, J. W., Koo, M. M., Hwang, Y. M., \& Pyun, S. B. (2016). Delayed non-word repetition according to rehearsal conditions in 6-to 7-year-old children. Communication Sciences \& Disorders, 21(1), 69-83.

Lim, H. C. (2004). Korean-reven colored progressive matrices(K-CPM). Seoul: Korean Guidance.

Murray, D. J. (1965). Vocalization-at-presentation and immediate recall, with varying presentation-rates. Quarterly Journal of Experimental Psychology, 17(1), 47-56.

Ryu, E. J., \& Ha, J. W. (2018). Development and application of nonsense syllable repetition test for evaluating phonological retrieval and sequencing abilities. Communication Sciences \& Disorders, 23(4), 992-1004.

Salame, P., \& Baddeley, A. (1982). Disruption of short-term memory by unattended speech: implications for the structure of working memory. Journal of verbal learning and verbal behavior, 21(2), 150-164.

Vallar, G., \& Papagno, C. (2002). Neuropsychological impairments of verbal short-term memory. In A. D. Baddeley, M. D. Kopelman, \& B. A. Wilson (Eds.), Handbook of memory disorders (2nd ed., pp. 249-270). Chichester: Wile. 
Appendix 1. The item list of the delayed digit span task

\begin{tabular}{lcc}
\hline & 4 Numbers & 6 Numbers \\
\hline Phonologically similar numbers & 8437 & 734812 \\
6952 & 438721 \\
8172 & 569438 \\
2187 & 348127 \\
7348 & 437812 \\
Phonologically dis-similar numbers & 1834 & 965217 \\
& 4378 & 217843 \\
& 3871 & 172569 \\
& 5316 & 623914 \\
& 9246 & 461392 \\
& 3628 & 514628 \\
& 9476 & 236145 \\
& 4163 & 391457 \\
& 8263 & 982647 \\
\hline
\end{tabular}




\section{국문초록}

\section{자극유형, 시연여부, 자극길이가 말소리장애 아동과 일반 아동의 음운작업기억 과제 수행에 미치는 영향 전은혜 ${ }^{1}$ 하지완 ${ }^{2}$}

'대구대학교 일반대학원 재활과학과 언어치료전공, ${ }^{2}$ 대구대학교 언어치료학과

배경 및 목적: 순수 말소리장애 아동(children with pure Speech Sound Disorder, pure SSD)과 일반 아동(typically developing peers, $\mathrm{TD})$ 의 음운작업기억에 영향을 미치는 변수를 살펴보고, 수행력을 인출과 배열의 측면에서 비교하였다. 방법: 자극유형(시각적 자극, 청각적 자극), 시연여부(외현적 시연, 시연억제), 자극길이(숫자 4 개, 6 개)를 고려하여 제작된 전산화된 지연 숫자 따라말하기를 pure SSD 18명과 TD 21명에게 실시하였다. 결과: 첫째, 집단 간 인출 수행력의 차이는 유의하지 않았으나, 집단 내 변수(자극유형, 시연여부, 자극길이)의 주효과는 모두 유의하였다. 삼요인 상호작용효과도 유의하였는데, 시연 조건에서는 두 자극길이 모두에서 시각자극의 인 출점수가 유의하게 좋았으나, 억제 조건에서는 4 항목에서만 자극유형 간 차이가 유의하였다. 둘째, 집단 간 배열 수행력에 대한 차이가 유의하지 않았으나, 집단 내 변수의 주효과는 모두 유의하였다. 시연여부와 집단 간 상호작용효과가 나타났는데, 시연 조건에서 자극길 이가 짧을 때 $\mathrm{TD}$ 의 배열점수가 유의하게 좋았다. 삼요인 상호작용효과 또한 유의하였는데, 시연 조건에서는 시각자극의 이득이 6 배열 에서 두드러진 반면, 억제 조건의 경우 시각자극의 이득이 4 배열에서 두드러졌다. 논의 및 결론: 본 연구의 결과는 음운작업기억의 촉 진 방법에 대해 의미 있는 정보를 제공한다. pure SSD의 경우 전반적인 음운작업기억 수행력은 $\mathrm{TD}$ 집단과 차이가 없었지만, 시연활동 의 효과는 $\mathrm{TD}$ 에 비해 제한적이었기 때문에 이들의 음운작업기억 촉진을 위해 또 다른 전략을 고민해볼 필요가 있다.

핵심어: 순수 말소리장애, 음운작업기억, 숫자 지연 따라말하기, 시각적 자극, 외현적 시연, 자극길이

이 논문은 2020학년도 대구대학교 학술연구비지원에 의한 논문임.

이 논문은 제 1 저자의 석사학위논문 내용을 바탕으로 작성되었음.

\section{참고문헌}

김명헌, 하지완 (2016). 청각적 말소리 자극과 시각적 글자 자극 제시방법에 따른 5, 6 세 일반 아동의 음소인식 수행력 비교. 말소리와 음성과학, 8(1), 71-80.

김미진, 하지완 (2019). 외현적 시연과 청각적 입력 강화가 말소리장애 아동과 일반 아동의 비단어 따라말하기 수행력에 미치는 영향. Communica-

tion Sciences \& Disorders, 24(1), 101-116.

김수진, 신지영 (2015). 말소리장애. 서울: 시그마프레스.

김옥향 (1997). 언어적 시연과제에서 연속 및 휴지조건이 회상기억에 미치는 효과. 유아교육학논집, 1(2), 239-262.

김영태, 성태제, 이윤경 (2004). 취학전 아동의 수용언어 및 표현언어 척도(PRES). 서울: 서울장애인종합복지관.

김영태, 신문자 (2004). 우리말조음·음운평가(U-TAP). 서울: 학지사.

김영태, 홍경훈, 김경희, 장혜성, 이주연 (2009). 수용·표현어휘력검사(REVT). 서울: 서울장애인종합복지관.

김지현 (2016). 노년층 이야기 담화의 정보단위산출: 시각과 청각 언어자극 간의 비교. 연세대학교 대학원 석사학위 논문.

류은주, 하지완 (2018). 음운 인출 및 배열 처리능력 평가를 위한 무의미 음절 따라말하기 검사의 개발 및 적용. Communication Sciences \& Disor-

ders, 23(4), 992-1004.

이기은, 하지완 (2018). 5세와 6세 말소리장애 아동의 음 운단기기억과 음운작업기억 능력. Communication Sciences \& Disorders, 23(3), 713-724.

이석정, 하지완, 구민모, 황유미, 편성범 (2016). 6, 7세 아동의 시연조건에 따른 지연 비단어 따라말하기 능력 비교. Communication Sciences \& Disorders, 21(1), 69-83.

이슬기, 임동선 (2017). 언어발달지연 아동의 외현적 시연(vocal rehearsal) 조건에 대한 비단어 산출 수행력. Communication Sciences \& Disorders, 
22(3), 471-484.

이은주, 심현섭 (2003). 무의미 음절 따라말하기를 통한 단순조음음운장애 아동과 정상아동의 음운기억 수행능력 비교연구. 언어청각장애연구, 8(2), 127-145.

임호찬 (2004). 한국판 Raven CPM 유아용 지능검사. 서울: 한국 가이던스.

정용석 (2012). 조음억제행동의 조작이 작업기억체계의 수행에 미치는 영향. 서울대학교 대학원 문학박사 학위논문.

정일권, 최선영, 하지완 (2015). 조음음운장애 아동과 일반 아동의 음운표상내적 인식능력 비교. Communication Sciences \& Disorders, 20(1), 48-59. 최현주 (2014). 고령자의 담화 이해 능력과 구어 작업기억 및 언어기억과의 상관. Communication Sciences \& Disorders, 19(4), 513-522. 황진경, 하승희 (2010). 2-5세 일반 아동의 무의미단어 따라말하기. 언어청각장애연구, 15(4), 561-571.

\section{ORCID}

전은혜(제1저자, 대학원생 https://orcid.org/0000-0001-9868-0937); 하지완(교신저자, 교수 https://orcid.org/0000-0002-1191-791X) 